\title{
STUDY OF EPIPHYTIC ALGAE ON Ceratophyllum demersum L. FROM TWO STATIONS AT SHATT AL-ARAB RIVER
}

\author{
Azhar A. Al-Saboonchi Hadel N. Al-Manshed \\ Department of Fisheries and Marine Resources \\ College of Agriculture - University of Basrah
}

\section{Abstract:}

This study is carried out on the epiphytic algae on Ceratophyllum demersum L. that collected from two different stations at Shatt al-Arab River to investigate the variations in quantity and quality of the epiphytic algae according to location of aquatic plant.

A total of 80 taxa of epiphytic algae were identified at two studied areas; diatoms were the dominant (57taxa) followed by Cyanobacteria (12 taxa) and Chlorophyta (11 taxa).

There were variations in the total algal species at two studied stations. Most of the identified algae were originally benthic but some were planktonic such as (Cyclotella spp.; Coscinodiscus sp.; Stephanodiscus sp.; Bacillaria paxillifer and Scenedesmus spp.).

Six species appeared during the study period; which may be due to their wide range in temperature tolerance. Higher value of BOD $^{5}(22-15 \mathrm{mg} / \mathrm{l})$ associated with higher quantity of Ceratophyllum demersum. This conclusion may apply on epiphytic algae which collected from this aquatic plant.

Key words: Diatoms, epiphytic algae, species composition, Shatt al-Arab, Ceratophyllum demersum, Biological oxygen demand.

\section{Introduction:}

Aquatic macrophytes play key ecological roles in river, primarily as a source of primary productivity and as habitat for abundant and diverse faunal communities (Toft et. al., 2003) such as epiphytic algae.

Epiphytic algal community appear an important fraction of the primary production of water body and are important as shelter and food for many invertebrates and fish(Cattaneo and Kalff,1987; Wetzel,1983;Woelkerling and Gough,1976).The relationship between epiphytic algae and their host macrophytes are poorly understood (Morin,1986).The epiphytic algae may reduce growth and production of aquatic plant (Takashi et. al.2004), in plants without epiphytic algae ,the net photosynthesis was significantly higher than in plants with epiphytic algae.Epiphytic owing to their close association with aquatic macrophytes 
may utilize dissolved organic matter products released by their hosts in freshwater habitates (Eminson, 1978).

Very limited information are available on the epiphytic algae in southern parts of the country ( Al-Kaisi,1964,Pankow et. al.,1979, Maulood et. al.,1981, Islam and Haroon,1983, Hadi and AlSaboonchi,1989 and Kassim and Al-Saadi ,1995). The present work is carried out on the epiphytic algae on Ceratophyllum demersum L., that collected from two different stations to investigate the variation in quantity and quality of epiphytic algae according to region of aquatic plant and the level of BOD..

\section{Materials and Methods:}

The Shatt al-Arab river is formed by the confluence of Tigris and Euphrates rivers at
Qurna and drains into the Arabian Gulf ,with a total length of about $120 \mathrm{Km}$.Near the banks of the river(about $1 \mathrm{~m}$. depth) there are submerged plants such as Ceratophyllum demersum ;Najas sp. Vallisneria sp.

Two stations at Shatt al-Arab River were selected for studying the epiphytic algae (Fig.1.). First station near Basra University, at Garmat Ali and second station at Abu Al-Gassib.Ceratophyllum demersum was selected as a host for epiphytic algae because it is abundant through out the year at two stations ,this aquatic plant is preferred for colonization by epiphytic -fauna in comparison to other submerged macrophyte species, due to highly dissected leaves ,the plant forms bowlshaped whorls set tightly together, and such morphological structure enables firmer attachment and protection for epiphytic organisms (Lalonde and Downing, 1991).
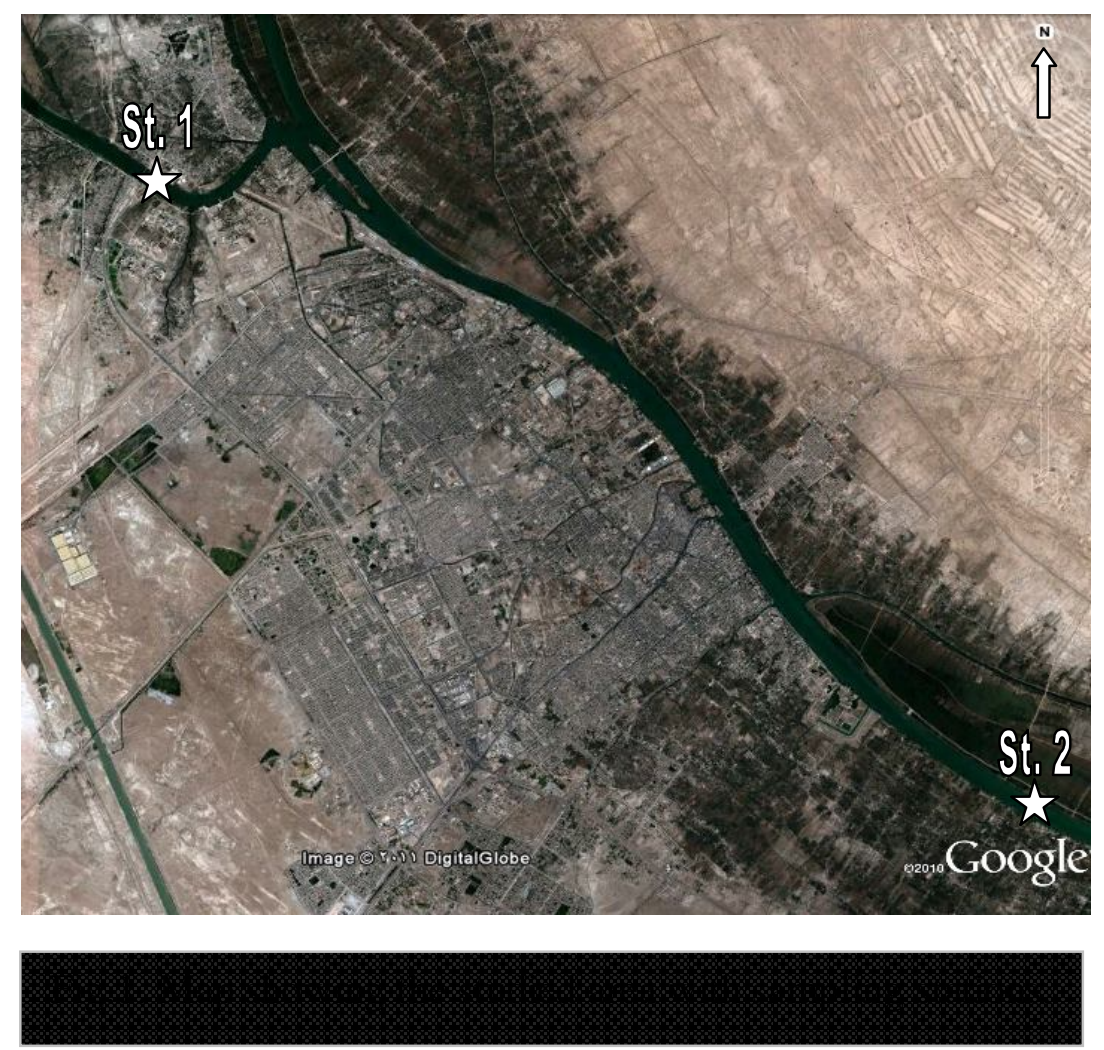
The sampling was done monthly from March to August, 2009 during low tide period of the day. Samples of Ceratophyllum demersum were taken from under water surface parts, avoiding few centimeters above the sediment. The samples were kept wet in polyethylene bags for laboratory study .Sub- sample of ten gram fresh weight were taken randomly .Separation of epiphytic algae were done by combination of vigorous shaking and sonication techniques as described by Bell(1976).

The biomass of $C$. demersum was estimated using rake with surface area of $0.16 \mathrm{~m}^{2}$, the biomass calculated per $\mathrm{m}^{2}$ of the bottom surface. Water samples were collected from two stations for determination Biological Oxygen Demand $\left(\mathrm{BOD}_{5}\right)$ as described by APHA (1985). Diatoms were identified after clearing the cells based on Patrick and Reimer (1975) and enumerated using modified microtransect method (Furet and Benson -Evans, 1982) .Enumeration of algae (nondiatoms) was done by haemocytometer as described by Martinez et. al.(1975).The result for counting were expressed as number of individual per one gram fresh weight of host plant.

\section{Results and Discussion:}

A total of 80 taxa of epiphytic algae were identified at two studied areas.As shown at table (1); diatoms were the dominant (57taxa) followed by Cyanobacteria (12 taxa) and Chlorophyta (11 taxa).There are variation in the total algal species at different station. A total of (49 taxa) epiphytic algae were recorded at station one (Garmat Ali); where's (56 taxa) were at station two (Abu AlGassib).Quantitative study showed that the mean of total algal number were $\left(249 \times 10^{5}\right.$ ind./gm. $)$ and $\left(188 \times 10^{5}\right.$ ind./gm. $)$ at stations one and two respectively.Most of the identified algae were originally benthic but some were planktonic such as (Cyclotella spp.; Coscinodiscus sp.; Stephanodiscus sp.; Bacillaria paxillifer and Scenedesmus spp.). Some species appeared during most months of study period such as (Cocconies placentula; Diploneis pseudovalis; Navicula parva; Nitzschia frustulum; Rhoicosphenia curvata and Synedra ulna) which may be due to their wide range in temperature tolerance as pointed out by Hickman and Klarer (1974).

Table (1): The identified epiphytic algae and their percentage on

Ceratophyllum demersum at the two stations.

\begin{tabular}{|c|c|c|}
\hline \multirow{2}{*}{ Taxa } & \multicolumn{2}{|c|}{ Station } \\
\hline & 1 & 2 \\
\hline \multicolumn{3}{|l|}{ - Cyanobacteria } \\
\hline Anabaena constricta (Sz.) Geitl. & 2.008 & 1.058 \\
\hline Chroococcus turgidus (Ktz.) Näg. & 0.402 & 1.058 \\
\hline Lyngbya limnetica Lemm. & 1.205 & ---- \\
\hline Lyngbya sp. & 0.803 & $-\cdots$ \\
\hline Merismopedia elegans A. Br. & 2.008 & 1.058 \\
\hline M. glauca (Ehr.) Näg. & $-\cdots$ & 1.058 \\
\hline Oscillatoria limnetica Lemm. & 0.803 & $\cdots$ \\
\hline O. limosa Ag. ex. Gomont & $\cdots$ & 1.058 \\
\hline O. tenuis C.A. Agardh & 1.205 & $-\ldots$ \\
\hline Oscillatoria sp. & 2.008 & $\cdots$ \\
\hline Rivularia sp. & 0.402 & $\cdots$ \\
\hline Spirulina major Ktz. & 1.606 & $-\cdots$ \\
\hline \multicolumn{3}{|l|}{ - Bacillariophyceae } \\
\hline \multicolumn{3}{|l|}{ - Centrales } \\
\hline Coscinodiscus sp. & $\cdots$ & 1.587 \\
\hline Cyclotella meneghiniana Ktz. & 0.402 & 1.587 \\
\hline C. striata (Ktz.) Grun. & 1.205 & 0.529 \\
\hline Melosira distans (Ehr.) Ktz. & 1.205 & 0.529 \\
\hline
\end{tabular}




\begin{tabular}{|c|c|c|}
\hline \multirow{2}{*}{ Taxa } & \multicolumn{2}{|l|}{ Station } \\
\hline & 1 & 2 \\
\hline M. varians Ag. & 2.008 & $-\cdots$ \\
\hline Stephanodiscus sp. & 0.402 & $-\cdots$ \\
\hline \multicolumn{3}{|l|}{ - Pennales } \\
\hline Achnanthes lanceolata Breb. & 1.205 & $-\cdots$ \\
\hline Achnanthes sp. & 0.402 & --- \\
\hline Amphora ovalis $\mathrm{Ktz}$ & $-\cdots$ & 2.645 \\
\hline Bacillaria paxillifer (Mull.) Hendey & $-\cdots$ & 1.058 \\
\hline Caloneis permagna (Bail.) Cl. & 0.402 & 1.058 \\
\hline C. ventricosa (Ehr.) Meist. & 0.402 & ---- \\
\hline C. pediculus Ehr. & 0.402 & 0.529 \\
\hline Cocconeis placentula var, euglypta (Ehr.) Cl. & 1.606 & 1.058 \\
\hline c. placentula var. lineata (Ehr.) Cl. & 4.016 & 22.222 \\
\hline Cymatopleura solea (Breb.) W. Smith & --- & 1.058 \\
\hline Cymbella affinis Ktz. & $-\cdots$ & 2.116 \\
\hline Cymbella aspera (Ehr.) Cl. & ---- & 1.586 \\
\hline c. microcephala Grun. & 0.402 & 1.058 \\
\hline c. tumida (Breb.) Van Heurck & --- & 1.586 \\
\hline c. ventricosa $\mathrm{Ktz}$. & 0.402 & 0.529 \\
\hline Diatoma vulagre Bory & 1.205 & --- \\
\hline Diploneis pseudovalis (Hus.) Patr. Rei. & 2.008 & 0.529 \\
\hline Epithemia sorex Ktz. & 0.402 & 1.586 \\
\hline Eunotia sp. & --- & 1.058 \\
\hline Fragilaria sp. & $-\cdots$ & 1.586 \\
\hline Gomphonema acuminatum var. turris (Ehr.) Cl. & $-\cdots$ & 1.058 \\
\hline G. augur Ehr. & 0.803 & 0.529 \\
\hline G. constrictum var. capitata (Ehr.) $\mathrm{Cl}$. & 0.402 & ---- \\
\hline Gyrasigma acuminatum (Ktz.) Rabh. & 1.205 & 0.529 \\
\hline G. spencerii var. nodifera Grun. & 0.402 & 0.529 \\
\hline G. tenuirostrum (Grun.) $\mathrm{Cl}$ & 0.803 & 0.529 \\
\hline Mastogloia smithii var. amphicephala Grun. & 0.402 & 1.586 \\
\hline Mastogloia sp. & --- & 0.529 \\
\hline Navicula atomus (Ktz.) Grun. & $-\cdots$ & 2.116 \\
\hline N. cryptocephala Ktz. & 0.402 & --- \\
\hline N. cuspidata & 0.402 & --- \\
\hline N. gracilis Ehr. & 0.803 & 0.529 \\
\hline N. parva (Mene.) $\mathrm{Cl}$. & 1.205 & 0.529 \\
\hline N. pseudatuscula Hust. & 1.205 & --- \\
\hline N. radiasa $\mathrm{Ktz}$ & 1.606 & $-\cdots$ \\
\hline N. rhynchocephala Ktz. & --- & 1.058 \\
\hline Nitzschia amphibia Grun. & --- & 2.460 \\
\hline N. apiculata (Greg.) Grun. & 2.008 & --- \\
\hline N. dissipata (ktz.) Grun. & 1.205 & $-\cdots$ \\
\hline \multirow{2}{*}{ Taxa } & \multicolumn{2}{|l|}{ Station } \\
\hline & 1 & 2 \\
\hline N. frustulum (Ktz.) Grun. & 6.827 & $-\cdots$ \\
\hline N. granulata Grun. & 2.008 & ---- \\
\hline N. hungarica Grun. & --- & 1.587 \\
\hline N. sigma (Ktz.) Sm. & $-\cdots$ & 1.587 \\
\hline N. sigmoidea (Ehr.) Sm. & $-\cdots$ & 1.058 \\
\hline Pinnularia brebissonii (Ktz.) Rab. & --- & 1.058 \\
\hline Rhoicasphenia curvata (Ktz.) Grun. & 6.024 & 1.058 \\
\hline Rhopaladia gibba (Ehr.) O.Muller & 1.205 & 0.529 \\
\hline R. gibberula (Ehr.) O.Muller & 2.811 & 1.058 \\
\hline Surirella ovalis Breb. & $-\cdots$ & 2.645 \\
\hline Synedra pulchella Ktz. & 0.803 & 1.587 \\
\hline S. uina (Nitz.) Ehr. & 35.743 & 10.582 \\
\hline \multicolumn{3}{|l|}{ - Chlorophyceae } \\
\hline Ankistrodesmus sp. & --- & 1.058 \\
\hline Bulbochaete sp. & --- & 1.587 \\
\hline Cladophora glomerata (L.) Ktz. & $-\cdots$ & 1.587 \\
\hline Coelastrum sp. & $-\cdots$ & 1.058 \\
\hline Mougeotia sp. & 0.402 & --- \\
\hline Pandorina morum (Muell.) Bary & $-\cdots$ & 1.587 \\
\hline Rhizoclonium sp. & --- & 1.058 \\
\hline Scenedesmum acuminatum (Lag.) Chod. & 0.803 & 2.645 \\
\hline S. dimorphus (Turp.) Ktz. & $-\cdots$ & 1.058 \\
\hline S. quadricauda (Turp.) de $\mathrm{Br}$. & $-\cdots$ & 1.587 \\
\hline Spirogyra sp. & 0.402 & 1.058 \\
\hline
\end{tabular}


The diatom dominancy in the present study was coincided with the previous studied in Iraqi water (Al-Mousawi et. al., 1990; Sabri, 1990; Kassim and Al-Saadi, 1995); and other aquatic ecosystems of other parts of the words (Anber, 1984; Adesalu et. al., 2008 and Magdaleng, et. al., 2008).
Number of different group of algae ,shown that diatoms and Cyanobacteria were higher at station one ,while diatoms with Chlorophyta appeared with high quantity at St two (Fig.2). Cyanobacteria and Chlorophyta appeared with low cell number during study period at stations two and one respectively and show no effect on population density .

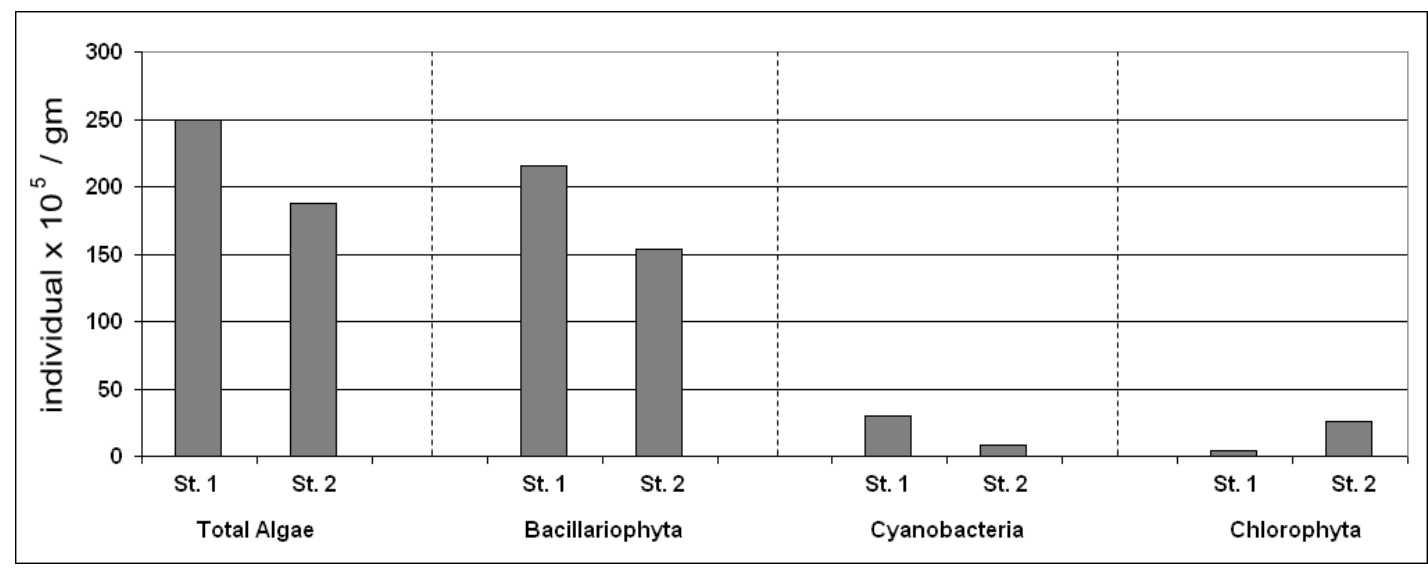

Fig.2. Total cell number of epiphytic algae and their major groups on Ceratophyllum demersum L. at two stations.

According to Adesalu, et. al. (2008), some physico-chemical characteristics influenced the epiphytic algal communities and deposition of domestic wastes probably enhanced the colonization of tolerant aquatic plant and epiphytic algae; the present study supported that conclusion, since at station one higher value of BOD $^{5} \quad(22-15 \mathrm{mg} / \mathrm{l})$ associated with higher quantity of Ceratophyllum demersum (table2).
This conclusion may apply on epiphytic algae which collected from surface of this aquatic plant, higher quantity were recorded at St.1 (Fig.2.). Values of BOD ${ }^{5}$ at St.2 lower and range between (9-6) $\mathrm{mg} / \mathrm{l}$.The presence of Merismopedia elegans and different species that belong to Oscillatoria, which were known to tolerate organically polluted water; were found with higher quantity at St.1.

Table (2): Biomass of Ceratophyllum demersum $\left(\mathrm{g} \mathrm{m}^{-2} \mathrm{ww}\right)$ at
two stations
\begin{tabular}{|l|l|l|l|l|l|l|}
\hline Site & March & April & May & June & July & August \\
\hline Garmat Ali & 460.2 & 530.3 & 701.6 & 722.8 & 680.1 & 620.3 \\
\hline Abu Al-Gassib & 251.4 & 380.9 & 400.1 & 420.3 & 411.9 & 390.8 \\
\hline
\end{tabular}

Results showed significant relationship between epiphytic algal quantity and biomass of the host plant; this result coincided with Cattaneo et. al. (1998).In Garmat Ali the average biomass of $C$. 
demersum was almost 2 times higher than that at Abu Al-Gassib (Table 2) and quantity of algae were higher too at this station.

The dominance of diatom species (e.g. Cocconeis placentula, which recorded with high quantity at St. 2) that is known as bioindicator of slightly alkaline and meso-eutrophic water (Toporowska, et. al., 2008).

\section{$\underline{\text { References: }}$}

Adesalu, T.A., T.O. Abiola and T.O. Bofia, 2008. Studies on the epiphytic algae associated with two floating aquatic Macrophytes in a sluggish nontidal polluted creek in Lagos, Nigeria. Asian J. Scientific Res., 1: 363-373.

Al-Kaisi,K.A.(1964).Contributions to the algal flora of ricefields of Souther-Eastern Iraq. Nova Hedw.27.813-827.

Al-Mousawi, A.H., R.A.Hadi, T.I.Kassim, and A.A.Al-Lami.(1990).A study on the algae in the Shatt al-Arab estuary ,southern Iraq.Mar.Mesopotamica.5,305-323.

Anber, R.M.S.(1984).Studies on the algae of polluted River Kelvin.Ph.D.Thesis, Univ.Glasgow U.K., 322pp.

APHA, 1985. Standard Methods for the Examination of Water and Wastewater. 20th Edn., American Public Health Association, Washington, DC., ISBN: 0875532357, pp: 1270.

Bell, D. (1976).The ecology of microalgae epiphytic on submerged macrophytes in eutrophic waterway.Ph.D.thesis, Uni.Liverpool.

Cattaneo, A.and J.Kalff. (1987).Seasonal changes in the epiphytic community of natural and artificial maophyes in lakes memphremagog. Hydrobiol.60 (2):135-144.

Cattaneo, A., Galanti, G., Gentinetta, S. and Susana, A. (1998), Epiphytic algae and macroinvertebrates

heterophyllum Mivhx.Fresh Water Biol.16:685-749. on submerged and floating-leaved macrophytes in an Italian lake. Freshwater Biology, 39: 725-740.

Eminson,D.F.(1978).A comparison of diatom epiphytes ,their diversity and density,attached to Myriophyllum spicatum L. in Norfolk dykes and broads.Br. Phycol.J.13,57-64.

Furet, J.E.and Benson-Evans, K. (1982).An evaluation of the time required to obtain complete sedimentation of fixed algal particles prior to enumeration . Br.Phycol.J.253-258.

Hadi, R.A.M., and A.A.Al-Saboonchi (1989).Seasonal variations of phytoplankton, epiphytic and epipelic algae in Shatt al-Arab River at Basrah, Iraq.Mar.Mesopotamica, 4,211-232.

Hickman,M.and Klarer,D.M.(1974).The growth of some epiphytic algal in a lake receiving thermal effluent.Arch.Hydrobiol.3,403-426.

Islam,A.K.M. and Haroon,A.K.Y.(1983). Studies on Chaetophoraceae from southern Iraq.Int.Rev. ges.Hydrobiol.68(3) 443-451.

Kassim,T.I.and Al-Saadi,H.A.(1995).Seasonal variation of epiphytic algal in marsh area,Iraq.Acta Hydrobiol.37(3):153-161.

Lalonde, S., Downing J.A., 1991, Periphyton biomass is related to lake trophic status, depth and macrophyte architecture. Can. J. Fish. Aq. Sci., 48, 2285-91

Magdalena T., B. Pawlik-Skowrońska, and A. Z. Wojtal .(2008). Epiphytic algae on Stratiotes aloides L., Potamogeton lucens L., Ceratophyllum demersum L. and Chara spp. in a macrophytedominated lake. Studies Intern. J .of Oceano and Hydrobiology Vol. XXXVII, No.2 .51-63.

Martinez,M.R.,Chakroff,R.P.,Pantastico,J.B.(1975). Note on direct phytoplankton counting technique using haemocytometer .Phil.Agric. 59,1-12.

Morin, J.O. (1986). Initial colonization of periphyton on natural and artificial species Of Myriophyllum 
Moulood, B.K., Hinton, G.C.F., Whitton, B.A. and AlSaadi ,H.A.(1981). On the algal ecology of the lowland Iraqi marshes .Hydrobiol.80, 269-276.

Pankow,H.,Al-Saadi,H.A.,Huq,F.M.and Hadi,R.A.M. (1979).On the algal flora of the marshes near Qurna (Southern Iraq)Willdenowia.8, 493-506.

Patrick,R., and Reimer C.R.(1975).The Diatoms of United States Acad.Nat.Sci.Philad. Monograph, 13,231pp.

Patrick, R., and Reimer, C. W. (1966). The diatoms of the United States exclusive of Alaska Hawaii. Monogr. Acad. Nat. Sci. Philadelphia, No. 13.

Sabri,A.W.(1990). Local and seasonal variation of epipelic algae in Samarra impoundment ,Iraq.Limnologica 21(1) 275-279.

Takashi Asaeda, Munira Sultana, Jagath Manatunge, Takeshi Fujino.(2004).

The effect of epiphytic algae on the growth and production of Potamogeton perfoliatus L. in two light conditions . Environmental and Experimental Botany, Volume 52, Issue 3, December 2004, Pages 225-238

Toporowska M., Pawlik-Skowrońska B., Wojtal A.Z., 2008, Epiphytic algae on Stratiotes aloides L., Potamogeton lucens L., Ceratophyllum demersum L. and Chara spp. in a macrophyte-dominated lake, Ocean. Hydrob. Studies, 37(2): 51

Toft,J.D.,Simenstad,C.A.,Cordell,J.R. and Grimaldo,L.F.(2003).The effect of introduced water hyacinth on habitat structure ,invertebrate assemblages, and fish duets.Estuaries.26:746-758.

Wetzel, R.G. (1983).Attached algal-substrata interactions: fact or myth and when and how? R.G. (ed.), periphyton of freshwater ecosystem .pp.207215.New York.

Woelkerling, W.J. and Gough, S.B. (1976).Wisconsin desmids .3.Desmid community composition and distribution in relation to lake type and water chemistry.Hydrobiol.51,3-32.

در اسة الطحالب الملتصقة على الثلنت .Ceratophyllum demersum L. في محطتين من شط العرب

$$
\text { أز هار الصابونجي }
$$

اجريت هذه الدراسـة لتحديد أنواع الطحالب الملتصقة على النبات المائي الثلنت والذي جمع من محطنيين مختلفتين من شط العرب لتحديد الاختلافات في نوعية وكمية الطحالب الملتصقة أعتمادا على منطقة تواجد النبات المائي.تم نشخيص 80 نوعا من الطحالب الملتصقة على النبـات المـائي (الثـلنت) وللمحطتين, الدايتومات هي السـائدة وتمتلها 57 نوع والطحالب الخضـر المزرقـة تتمثل ب12 نوع بينما تم تشخيص 11 نوع تعود للطحالب الخضراء.هناللك أختلافات بالمجموع الكلي للانواع المسجلة بين المحطنين .اغلب الطحالب المشخصة اصلها و قاعي وقسم منها هائم مثل . Bacillaria paxillifer و Stephanodiscus sp. Coscinodiscus sp. و Cyclotella spp . ظهرت ست أنواع بشكل مستمر خلال فترة الدراسة والسبب يعود الى قابلية تحملها لمدى واسـع من التغيرات في Scenedesmus spp. درجات الحرارة ـ تراوحت قيم المنطلب الحياتي للاوكسجين ما بين (22 -15) ملغم/لتر ورافقتها كميات عالية من النبات المائي وهذا بنطبق على الطحالب الملتصقة حيث ازدادت أعدادها في الموقع الذي يمناز بأرتفاع قيم المنطلب الحياتي للأوكسجين. 